\title{
Pengaruh Pemberian Minuman Kombinasi Sari Kurma (Phoenix dactylifera) dan Garam NaCl terhadap Tekanan Darah dan Lama Periode Pemulihan Denyut Nadi pada Atlet Sepak Bola
}

\author{
Efrilia Maulana ${ }^{1}$, Siti Wahyuningsih ${ }^{1}$, Natalia Desy Putriningtyas ${ }^{2 *}$ \\ ${ }^{1}$ Program Studi S-1 Ilmu Gizi Fakultas Ilmu Kesehatan Universitas Respati Yogyakarta \\ ${ }^{2}$ Gizi S1 Ilmu Kesehatan Masyarakat Fakultas Ilmu Keolahragaan Universitas Negeri \\ Semarang \\ *email: natalia.desy12@gmail.com
}

\begin{abstract}
The athlete's achievement is related to the athlete's performance in a match. The performance can be seen in blood pressure and pulse. The administration of carbohydrateelectrolyte drinks influenced blood pressure and pulse. Drinks combination of sari dates and $\mathrm{NaCl}$ contain carbohydrates and electrolytes which helps to improve the performance of athletes by delaying fatigue. This research to determine the effect of combination palm juice extracts and $\mathrm{NaCl}$ on blood pressure and the period of recovery of the pulse of a soccer athlete. The quasi-experimental cross over study was completed. This research was carried out in the Wates square. Subjects in this study were Hizbul Wathan Wates Football School (SSB) athletes. The subjects received one experimental used $300 \mathrm{ml}$ combination drink of palm juice and $\mathrm{NaCl}$ or control drink, namely sugar water after a washout period of six days. Blood pressure measurements were carried out fifteen minutes before exercise and fifteen minutes after exercise, while pulse measurements were carried out fifteen minutes before exercise and five minutes, ten minutes, fifteen minutes after exercise. The statistical test used was Shapiro Wilk, Paired t-test and Independent T-test. The results of statistical analysis showed that there was no significant effect on the combination of dates, and $\mathrm{NaCl}$ combined with systole and diastolic blood pressure $(p>0.05)$, and there was a significant effect on the combination of dates palm juice and $\mathrm{NaCl}$ on pulse recovery five minutes, ten minutes and fifteen minutes after exercise $(p<0.05)$. There was no significant effect on the combination of date palm juice and $\mathrm{NaCl}$ on blood pressure, and there was a significant effect on the combination of dates and $\mathrm{NaCl}$ combination drinks on the recovery of pulse five minutes, ten minutes and fifteen minutes after exercise.
\end{abstract}

Keywords: Dates, $\mathrm{NaCl}$, Soccer, Blood Pressure, Pulse 


\section{PENDAHULUAN}

Sepak bola merupakan olah raga populer dan sering dimainkan di berbagai negara termasuk Indonesia. Pencapaian prestasi atlet sepak bola di Indonesia yang masih rendah dibuktikan pada kompetisi di Asia youth game, Indonesia masih tertahan di perempat final (PSSI, 2013).

Tim sepak bola Indonesia U-23 juga dikalahkan oleh tim Thailand pada final SEA Games XXVII (Tomas, 2013), sedangkan di Yogyakarta sendiri, tim Daerah Istimewa Yogyakarta hanya mampu meraih posisi runner up pada Pekan Olahraga Mahasiswa Nasional (POMNAS) setelah dikalahkan oleh tim

Daerah Khusus Ibu Kota Jakarta (Herawati, 2013).

Pembinaan sepak bola usia dini melalui sekolah sepak bola dan kompetisi antar sekolah sekolah merupakan sarana dalam meningkatkan prestasi sepak bola di Yogyakarta ataupun tingkat nasional. Salah satu sekolah sepak bola yang terdapat di Yogyakarta khusus nya di Kabupaten Kulon Progo adalah sekolah sepak bola Hizbul Wathan (HW) Wates.

Sekolah sepak bola Hizbul Wathan (SSB HW) Wates merupakan klub sepak bola yang berdiri pada tahun 2010. Sekolah Sepak Bola Hizbul Wathan (SSB HW) Wates berhasil menjadi juara di Jurnal Gizi Volume 8 No 2 Tahun 2019 divisi I, dan HW Wates berhak promosi ke divisi utama. Atlet sepak bola harus menjaga dan meningkatkan performa selama latihan dan pertandingan untuk meningkatkan prestasinya (Guyton dan Hall, 2008)

Prestasi atlet ini berkaitan dengan performa yang menjadi salah satu penentu kemenangan pada sebuah pertandingan. Salah satu cara yang dapat mewakili pengukuran performa atlet adalah pengukuran tekanan darah dan denyut nadi (William, 2007).

Peningkatan tekanan darah, denyut nadi, osmolalitas plasma bahkan kepadatan volume darah dapat dipicu melalui pengeluaran keringat pada saat seseorang melakukan olah raga. Cairan yang diberikan setelah berolahraga dapat efektif menurunkan kepadatan volume darah, menjaga status hidrasi dan mempercepat proses recovery (Irianto, 2007). Untuk menunjang perfoma atlet yang optimal, seorang atlet harus memperhatikan asupan cairan yang dikonsumsi baik pada saat latihan maupun pertandingan (Kirkendall, 2004).

Pemberian makanan atau minuman karbohidrat selama pertandingan terbukti memperbaiki performa pada babak kedua pertandingan sepak bola (Singh, 2011). Penundaan kelelahan pada atlet yang pada akhirnya meningkatkan performa atlet dilakukan melalui minuman dengan kadar 
karbohidrat $6-8 \%$ selama latihan atau pertandingan. Penelitian menunjukan bahwa pemberian cairan karbohidrat selama 60-15 menit sebelum latihan dapat meningkatkan performa dan menunda kelelahan pada atlet (Murray, 2001).

Salah satu sumber karbohidrat yang dapat digunakan untuk memperbaiki performa yaitu buah kurma. Kurma (Phoenix dactylifera) memiliki komponen utama karbohidrat dengan unsur monosakarida glukosa, fruktosa dan sukrosa (Afriani, 2014). Kandungan karbohidrat yang tinggi dapat digunakan untuk salah satu sumber energi dalam tubuh untuk meningkatkan performa atlet (Murray, 2001). Bahan selain kurma yang dapat digunakan untuk memperbaiki performa adalah garam $\mathrm{NaCl}$. Garam $\mathrm{NaCl}$ memiliki kandungan mineral yang berperan mengatur keseimbangan elektrolit tubuh (Afriani, 2014).

METODE PENELITIAN

Jenis penelitian ini adalah penelitian quasi experimental menggunakan rancangan same subject design dengan periode wash out selama enam hari. Periode washout bertujuan untuk menghilangkan pengaruh intervensi dan subyek diperkenankan melakukan aktivitas seperti biasa. Intervensi akan diberikan satu kali/hari.

Perhitungan subyek penelitian menggunakan rumus Lemeshow dan diperoleh subyek sebanyak 14 orang. Teknik pemilihan subyek penelitian menggunakan purposive sampling dengan kriteria inklusi berjenis kelamin laki-laki, usia 15-20 tahun, IMT/U normal, tingkat keterlatihan minimal latihan 3 bulan rutin dan bersedia menjadi subyek penelitian dengan menandatangi informed consent.

Bahan

Kelompok intervensi pada penelitian ini menggunakan minuman kombinasi $12,5 \%$ (8\%) sari kurma dan 0,5 gram garam $\mathrm{NaCl}$ yang dilarutkan dalam $300 \mathrm{ml}$ air. Kelompok kontrol menggunakan empat gram glukosa yang dilarutkan dalam $300 \mathrm{ml}$ air.

Alat

Instrumen yang digunakan dalam penelitian ini adalah buku petunjuk penelitian, formulir informed consent, formulir identitas responden, formulir Semi Quantitative Food Frequency Questionnaire (SQFFQ), formulir aktivitas fisik, timbangan injak digital, microtoise, dan alat pengukur tekanan darah dan denyut nadi digital, stopwatch. Kalibrasi timbangan injak digital dan microtoise sudah dilakukan sebelum alat digunakan dalam penelitian.

\section{Tahapan Penelitian}

Tahapan persiapan pada penelitian ini diawali dengan recruitment dan melakukan pengukuran karakteristik subyek. Tahapan selanjutnya adalah pemberian minuman air 
gula sebanyak $300 \mathrm{ml}$ sebagai kontrol sekaligus pengukuran tekanan darah dan denyut nadi 15 menit sebelum latihan. Setelah subyek selesai latihan dilakukan pengukuran denyut nadi pada menit kelima, kesepuluh dan kelimabelas dilanjutkan pengukuran tekanan darah. Subyek akan memasuki periode washout selama enam hari setelah pemberian minuman kontrol.

Subyek akan kembali dilakukan pengukuran denyut nadi dan tekanan darah 15 menit sebelum latihan kemudian diberikan minuman kombinasi sari kurma dan garam $\mathrm{NaCl}$. Setelah subyek selesai melakukan latihan maka dilakukan pengukuran denyut nadi pada menit kelima, kesepuluh dan kelima belas dilanjutkan dengan pengukuran tekanan darah (Afriani, 2014). Tekanan darah diukur oleh enumerator yang telah mendapatkan Ketrampilan Dasar Perawat menggunakan alat pengukur tekanan darah digital merk onemed. Denyut nadi diukur menggunakan metode palpasi menggunakan jari telunjuk dan jari tengah serta dihitung berdasarkan waktu menggunakan stopwatch. Uji Statistik

Shapiro wilk digunakan untuk mengetahui normalitas data. Pengaruh pemberian kombinasi sari kurma dan garam $\mathrm{NaCl}$ sebelum dan sesudah intervensi menggunakan uji paired t-test. Uji independent t-test digunakan untuk Jurnal Gizi Volume 8 No 2 Tahun 2019 menganalisis perbedaan antara kelompok kontrol dengan kelompok intervensi. Ethical clearance dari Komisi Etik Universitas RespatiYogyakarta telah diperoleh sebelum penelitian dilakukan dengan No 087.2/UNRIYO/PL/IV/2018.

\section{HASIL DAN PEMBAHASAN}

Seluruh subyek yang terlibat dalam penelitian ini adalah atlet Sekolah Sepak Bola Hizbul Wathan (SSB HW) Wates. Tabel 1 menjelaskan mengenai karakteristik subyek seperti usia, berat badan, tinggi badan, indeks massa tubuh (IMT) menurut umur dan aktivitas fisik. Nilai median usia subyek adalah 17 tahun dengan usia maksimal 17 tahun dan minimal 15 tahun. Rerata berat badan subyek $56,96 \pm 4,38 \mathrm{~kg}$ dengan berat badan maksimal serta minimal masingmasing $66,30 \mathrm{~kg}$ dan 49,20 kg. Rerata tinggi badan subyek $165,76 \pm 4,73 \mathrm{~cm}$ dengan tinggi badan maksimal 174,50 cm serta tinggi badan minimal 159,00 cm. Rerata IMT/U subyek $0,37 \pm 0,22 \mathrm{SD}$ dengan nilai IMT/U maksimal 0,76 SD dan nilai IMT/U minimal 0,04 SD. Nilai median aktivitas fisik subyek 1,04 PAL dengan nilai aktivitas fisik maksimal 2,04 PAL dan nilai aktivitas minimal 1,04 PAL. Tabel 2 menunjukkan bahwa rerata asupan

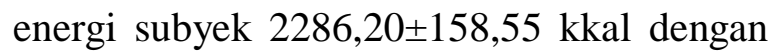
dengan nilai asupan energi maksimal 2534,00 kkal dan nilai asupan energi minimal 2077,00 kkal. Rerata asupan protein subyek $92,21 \pm 8,81 \mathrm{~g}$ dengan nilai asupan protein maksimal 109,00 g dan nilai asupan protein 
minimal 80,00 g. Rerata asupan lemak subyek 56,28 $\pm 8,77 \mathrm{~g}$ dengan nilai asupan lemak maksimal 69,00 g dan nilai asupan lemak minimal 36,00 g. Nilai median asupan karbohidrat subyek 330,50 g dengan nilai asupan karbohidrat maksimal $545,00 \mathrm{~g}$ dan nilai asupan karbohidrat minimal 257,00 g. Rerata asupan cairan subyek 2.792,90 $\pm 275,86 \mathrm{ml}$ dengan nilai asupan cairan maksimal 3.200,00 ml dan nilai asupan cairan minimal 2.300,00 $\mathrm{ml}$. Tidak ada pengaruh signifikan $(p>0,05)$ pemberian minuman kombinasi sari kurma dan garam $\mathrm{NaCl}$ terhadap tekanan darah sistol dan diastol sebelum latihan dan 15 menit setelah latihan, dengan signifikansi tekanan darah sistol sebesar $p=0,066$ dan tekanan darah diastol sebesar $p=0,530$. Kelompok kontrol menunjukkan tidak ada pengaruh yang signifikan $(p>0,05)$ pemberian minuman kontrol terhadap tekanan darah sistol dan diastol sebelum latihan dan 15 menit setelah latihan, dengan signifikansi tekanan darah sistol sebesar $p=0,829$ dan tekanan darah diastol sebesar $p=0,119$. Tabel 4 menunjukkan bahwa tidak ada perbedaan yang signifikan $(p>0,05)$ pada kelompok perlakuan dan kontrol terhadap tekanan darah sistol dan diastol sebelum latihan dan 15 menit setelah latihan. Nilai signifikasi sebelum latihan pada tekanan darah sistol dan diastol sebesar $p=0,508$ dan $p=0,703$. Nilai signifikansi 15 menit setelah latihan pada Jurnal Gizi Volume 8 No 2 Tahun 2019 tekanan darah sistol dan diastol sebesar $p=0,161$ dan $p=0,061$. Tabel 5 menunjukkan bahwa ada pengaruh yang signifikan $(\mathrm{p}<0,05)$ pemberian minuman kombinasi sari kurma dan garam $\mathrm{NaCl}$ terhadap denyut nadi sebelum latihan, 5 menit setelah latihan, 10 menit setelah latihan dan 15 menit setelah latihan, dengan signifikansi denyut nadi sebelum latihan dan 5 menit setelah latihan sebesar $p=0,000$, denyut nadi 5 menit dan 10 menit setelah latihan sebesar $p=0,000$ dan denyut nadi-10 menit dan 15 menit setelah latihan sebesar $p=0,001$. Kelompok kontrol menunjukkan ada pengaruh yang signifikan $(\mathrm{p}<0,05)$ pada pemberian minuman kontrol terhadap denyut nadi sebelum latihan, 5 menit setelah latihan, 10 menit setelah latihan dan 15 menit setelah latihan, dengan signifikansi denyut nadi sebelum latihan dan 5 menit setelah latihan sebesar $p=0,000$, denyut nadi 5 menit dan 10 menit setelah latihan sebesar $p=0,002$ dan denyut nadi 10 menit dan 15 menit setelah latihan sebesar $p=0,004$.

Tabel 6 menunjukkan bahwa terdapat perbedaan yang signifikan $(p<0,05)$ pada kelompok perlakuan dan kontrol terhadap denyut nadi sebelum latihan, 5 menit setelah latihan, 10 menit setelah latihan dan 15 menit setelah latihan. Nilai signifikansi denyut nadi sebelum latihan sebesar $p=0,007$, denyut nadi 5 menit setelah latihan sebesar $p=0,004$, denyut nadi 10 menit setelah latihan sebesar $p=0,000$ dan denyut nadi 15 menit setelah 
latihan sebesar $p=0,001$.

Tabel 1 Karakteristik Subyek Penelitian

Karakteristik Subyek N Mean \pm SD

\begin{tabular}{lll}
\hline Usia (tahun) & 14 & $17,00(15,00-17,00)^{*}$ \\
Berat badan $(\mathrm{kg})$ & 14 & $56,96 \pm 4,38$ \\
Tinggi badan $(\mathrm{cm})$ & 14 & $165,76 \pm 4,73$ \\
IMT/U (SD) & 14 & $0,37 \pm 0,22$ \\
Aktivitas fisik (PAL) & 14 & $1,04(1,04-2,04)$ \\
\hline
\end{tabular}

Keterangan: *Median (min-max)

Tabel 2 Kebiasaan Makan Subyek

\begin{tabular}{lll}
\hline Asupan Zat Gizi & N & Mean \pm SD \\
& & \\
\hline Energi (kkal) & 14 & $2286,20 \pm 158,55$ \\
Protein (g) & 14 & $92,21 \pm 8,81$ \\
Lemak (g) & 14 & $56,28 \pm 8,77$ \\
Karbohidrat (g) & 14 & $330,50(257,00-545,00)^{*}$ \\
Cairan (ml) & 14 & $2792,90 \pm 275,86$ \\
\hline Keterangan:*Median (min-max)
\end{tabular}

Tabel 3 Pengaruh Pemberian Minuman pada Kelompok Perlakuan dan Kelompok Kontrol Terhadap Tekanan Darah

\begin{tabular}{|c|c|c|c|c|}
\hline Kelom & & $\underline{P 1}$ & P2 & $\triangle P$ \\
\hline pok & & Mean \pm SD & Mean \pm SD & \\
\hline \multirow[t]{2}{*}{ Perlakuan } & Sistol & $132,93 \pm 13,01$ & $121,36 \pm 15,06$ & $-11,570,066^{*}$ \\
\hline & Diastol & $82,78 \pm 4,85$ & $81,14 \pm 7.97$ & $-1,640,530^{*}$ \\
\hline \multirow[t]{2}{*}{ Kontrol } & Sistol & $129,07 \pm 17,09$ & $130,04 \pm 18,08$ & $0,97 \quad 0,829 *$ \\
\hline & Diastol & $81,35 \pm 12,89$ & $88,14 \pm 8,37$ & $6,790,119 *$ \\
\hline
\end{tabular}

*tidak signifikansi untuk $p>0,05$ dengan uji Paired TTest

P1: Pengukuran Tekanan Darah Sebelum latihan $(\mathrm{mmHg})$

P2: Pengukuran Tekanan Darah 15 Menit setelah latihan (mmHg)

Perlakuan : Minuman kombinasi sari kurma dan garam $\mathrm{NaCl}$

Kontrol : Air gula

Tabel 4 Perbedaan Pemberian Minuman pada

Kelompok Perlakuan dan Kelompok Kontrol

Terhadap Tekanan Darah

\begin{tabular}{|c|c|c|c|c|}
\hline $\begin{array}{l}\text { Kelom } \\
\text { pok }\end{array}$ & P1 & $\mathbf{P 2}$ & P3 & P4 \\
\hline Perlakuan & $132,93 \pm 13,01$ & $82,78 \pm 4,85$ & $121,36 \pm 15,06$ & $81,14 \pm 7,97$ \\
\hline \multirow[t]{3}{*}{ Kontrol } & $129,07 \pm 17,09$ & $81,35 \pm 12,89$ & $130,43 \pm 18,08$ & $88,14 \pm 8,37$ \\
\hline & $-3,86$ & $-1,43$ & 9,07 & 7 \\
\hline & $0,508^{*}$ & $0,703^{*}$ & $0,161 *$ & $0,061^{*}$ \\
\hline
\end{tabular}

Keterangan:

P1: Tekanan Darah Sistol Sebelum latihan ( $\mathrm{mmHg}$ )

P2: Tekanan Darah Diastol Sebelum latihan $(\mathrm{mmHg})$

P3: Tekanan Darah Sistol 15 Menit setelah latihan $(\mathrm{mmHg})$

P4: Tekanan Darah Diastol 15 Menit setelah latihan $(\mathrm{mmHg})$

Perlakuan : Minuman kombinasi sari kurma dan garam $\mathrm{NaCl}$

Kontrol : Air gula
Tabel 5 Pengaruh Pemberian Minuman pada Kelompok Perlakuan dan Kelompok Kontrol Terhadap Denyut Nadi

\begin{tabular}{|c|c|c|c|c|c|c|c|}
\hline $\begin{array}{l}\text { Kelom } \\
\text { pok }\end{array}$ & P0 & P1 & P2 & P3 & $\begin{array}{l}P 1 \\
(0 \& 1)\end{array}$ & $\begin{array}{l}P 2 \\
(1 \& 2)\end{array}$ & $\begin{array}{l}P 3 \\
(2 \& 3)\end{array}$ \\
\hline Perlakuan & $88,21 \pm$ & $105,71 \pm$ & $92,28 \pm$ & $80,42 \pm$ & $0,000 *$ & $0,000^{*}$ & $0,001 *$ \\
\hline & 7,70 & 9,79 & 11,30 & 8,41 & & & \\
\hline Kontrol & $\begin{array}{l}73,35 \pm \\
16,69\end{array}$ & $\begin{array}{l}118,93 \pm \\
12,33\end{array}$ & $\begin{array}{l}109,50 \pm \\
8,72\end{array}$ & $\begin{array}{l}94,28 \pm \\
11,73\end{array}$ & $0,000 *$ & $0,002^{*}$ & $0,004 *$ \\
\hline
\end{tabular}

Keterangan:

Data dinyatakan dalam mean \pm standar deviasi

*Signifikansi untuk $p<0,05$ dengan uji Paired T Test

P0: Pengukuran Denyut Nadi Sebelum latihan (kali/menit)

P1: Pengukuran Denyut Nadi 5 Menit setelah latihan (kali/menit)

P2: Pengukuran Denyut Nadi 10 Menit setelah latihan(kali/menit)

P3: Pengukuran Denyut Nadi 15 Menit setelah latihan(kali/menit)

Perlakuan : Minuman kombinasi sari kurma dan garam $\mathrm{NaCl}$

Kontrol : Air gula

Tabel 6 Perbedaan Pemberian Minuman pada Kelompok Perlakuan dan Kelompok Kontrol Terhadap Denyut Nadi

\begin{tabular}{lllll}
\hline Kelompok & P1 & P2 & P3 & P4
\end{tabular}

\begin{tabular}{llllll}
\hline Perlakuan & $88,21 \pm 7,70$ & $105,71 \pm 9,79$ & $92,28 \pm 11,30$ & $80,42 \pm 8,41$
\end{tabular}

Kontrol $\quad 73,35 \pm 16,69 \quad 118,93 \pm 12,33 \quad 109,50 \pm 8,72 \quad 94,28 \pm 11,7$

\begin{tabular}{rrrrr}
\hline$\Delta$ & $-14,86$ & 13,22 & 17,22 & 13,86
\end{tabular}

$$
\begin{array}{lll}
P & 0,007 * \quad 0,004 *
\end{array}
$$

$0,000 * \quad 0,001 *$

\section{Keterangan:}

*Signifikansi untuk $p<0,05$ dengan uji Paired T Test

P1: Pengukuran Denyut Nadi Sebelum latihan (kali/menit)

P2: Pengukuran Denyut Nadi 5 Menit setelah latihan (kali/menit)

P3: Pengukuran Denyut Nadi 10 Menit setelah latihan(kali/menit) P4: Pengukuran Denyut Nadi 15 Menit setelah latihan (kali/menit) Perlakuan: Minuman kombinasi sari kurma dan garam $\mathrm{NaCl}$ Kontrol : Air gula

\section{Karakteristik Subyek}

Karakteristik subyek yang diamati adalah usia, berat badan, tinggi badan, indeks massa tubuh (IMT) menurut umur dan aktivitas fisik. Subyek yang terlibat dalam penelitian ini adalah atlet SSB HW Wates sebanyak 14 orang atlet.

Pada penelitian ini subyek berusia 15 sampai 17 tahun dengan 12 subyek memiliki aktivitas fisik ringan dan dua subyek dengan kategori 
aktivitas fisik berat.

\section{Asupan Subyek Penelitian}

Pada penelitian ini, data asupan makan subyek yang dianalisis adalah data kebiasaan makan subyek. Satu hari sebelum intervensi dilakukan wawancara pada subyek menggunakan formulir SQFFQ. Berdasarkan hasil analisis menunjukkan bahwa asupan energi, protein, lemak dan cairan subyek terdistribusi normal dan menunjukkan homogenitas subyek berdasarkan asupan energi, protein, lemak dan cairan. Berdasarkan hasil analisis asupan karbohidrat tidak terdistribusi normal dan tidak menunjukkan homogenitas berdasarkan asupan karbohidrat.

3. Pengaruh Pemberian Minuman Kombinasi Sari Kurma dan $\mathrm{NaCl}$ terhadap Tekanan Darah

Minuman kombinasi sari kurma dan garam $\mathrm{NaCl}$ sebanyak 300 ml dengan frekuensi satu kali pemberian diberikan sebelum subyek melakukan pengukuran tekanan darah. Pengukuran tekanan darah dilakukan dua kali yaitu 15 menit sebelum latihan fisik dan 15 menit setelah latihan fisik. Berdasarkan hasil uji statistik menunjukkan bahwa Jurnal Gizi Volume 8 No 2 Tahun 2019 rerata tekanan darah sistol dan diastol 15 menit setelah latihan mengalami penurunan. Hasil uji statistik menunjukkan bahwa tidak terdapat pengaruh signifikan pemberian minuman pada kelompok perlakuan terhadap tekanan darah sistol dan diastol sebelum latihan dan 15 menit setelah latihan. Penelitian ini sejalan dengan Afriani (Afriani, 2014) yang menyebutkan bahwa pemberian minuman kombinasi maltodekstrin dan vitamin C sebanyak $300 \mathrm{ml}$, tidak memberikan pengaruh yang signifikan pada tekanan darah sistol dan diastol pada atlet sepak bola. Hal ini terjadi karena pengaruh situasi lingkungan yang dapat mempengaruhi hasil pengukuran tekanan darah pada atlet terutama karena faktor suhu (Halonen, 2010). Tekanan darah dapat menurun dikarenakan adanya peningkatan suhu tubuh sehingga merangsang pengeluaran keringat yang menyebabkan plasma darah keluar sehingga volume darah menurun. Peningkatan suhu tubuh mengakibatkan kehilangan cairan sebesar $5-6 \%$ dari berat badan. Tubuh akan selalu mengupayakan dalam kondisi suhu tubuh normal meskipun sedang dalam kondisi hypertermi. Air merupakan cairan paling baik untuk menurunkan suhu tubuh yang disertai dehidrasi 
(Krisnawati, 2011).

Pada penelitian ini subyek juga diberikan minuman kontrol yaitu air gula sebanyak $300 \mathrm{ml}$ dengan frekuensi satu kali pemberian. Hasil uji statistik menunjukkan bahwa tidak terdapat pengaruh signifikan pemberian minuman pada kelompok kontrol terhadap tekanan darah sistol dan diastol sebelum latihan dan 15 menit setelah latihan. Hal ini sejalan dengan penelitian Meludu et al (Meludu, 2005) bahwa tidak ada perubahan yang signifikan pada tekanan darah pada pemberian minuman dengan satu gram glukosa dalam $250 \mathrm{ml}$ air.

Hasil uji tatistik menunjukkan bahwa tidak ada perbedaan yang signifikan $(p>0,05)$ pada kelompok perlakuan dan kontrol terhadap tekanan darah sistol dan diastol sebelum latihan dan 15 menit setelah latihan. Penelitian ini menunjukkan bahwa minuman yang diberikan pada kelompok perlakuan memiliki efek yang sama dengan minuman pada kelompok kontrol. Hal tersebut karena jumlah glukosa pada minuman kelompok perlakuan dan kelompok kontrol juga sama, yaitu empat gram glukosa.

Minuman pada kelompok perlakuan dan kelompok kontrol Jurnal Gizi Volume 8 No 2 Tahun 2019 mengandung $8 \%$ karbohidrat, jumlah tersebut telah sesuai dengan syarat minuman olahraga yang menyatakan bahwa kandungan karbohidrat 6-8\% selama latihan atau pertandingan dapat membantu meningkatkan performa atlet dengan menunda kelelahan (Dorfman, 2008). Minuman pada kelompok perlakuan dibuat dengan mempertimbangkan nilai osmolaritas.

$\mathrm{NaCl}$ yang digunakan dalam minuman kelompok perlakuan sebanyak $500 \mathrm{mg}$ atau 28,54 mOsm. Konsentrasi natrium 20 sampai 50 $\mathrm{mmol} / \mathrm{L}$ dapat membantu memulihkan memulihkan volume plasma dan keseimbangan cairan (Koswara, 2009).

4. Pengaruh Pemberian Minuman Kombinasi Sari Kurma dan NaCl terhadap Denyut Nadi

Pada penelitian ini subyek diberikan minuman kombinasi sari kurma dan garam $\mathrm{NaCl}$ sebanyak 300 mi sebanyak satu kali per hari. Minuman kombinasi ini mengandung $8 \%$ karbohidrat (4,104 g glukosa) dan 500 mg NaCl. SNI 01-4452- 1998 menyebutkan bahwa minuman isotonik harus mengandung gula (minimal 5\%) dan mineral (Na maksimal 800-1000 $\mathrm{mg} / \mathrm{kg}$ ). Minuman kombinasi sari kurma dan garam $\mathrm{NaCl}$ ini sudah sesuai dengan SNI 01-4452-1998, yaitu karbohidrat yang digunakan $8 \%$ dan natrium 500 
mg.

Hasil uji statistik menyatakan bahwa terdapat pengaruh yang signifikan pada pemberian minuman pada kelompok perlakuan terhadap denyut nadi sebelum latihan, lima menit setelah latihan, 10 menit setelah latihan dan 15 menit setelah latihan dengan nilai $p<0,05$. Hasil penelitian ini sejalan dengan penelitian Saharullah yang menyatakan bahwa pemulihan denyut nadi dengan pemberian minuman isotonik lebih baik daripada pemulihan denyut nadi dengan pemberian air putih pada pemain Hoki FIK UNM. Pemulihan denyut nadi yang lebih baik ini dikarenakan pada larutan glukosa mengandung elektrolit (isotonik) sehingga memudahkan penyerapan oleh usus halus secara difusi aktif daripada air. Glukosa juga berperan dalam meningkatkan reabsorpsi natrium ataupun kebalikannya natrium juga berguna dalam absorpsi glukosa. Minuman isotonik memberikan efek yang lebih cepat dalam pemulihan denyut nadi dikarenakan mudah diserap oleh usus. Hasil penelitian ini juga sejalan dengan penelitian Hidajah yang menyatakan bahwa minuman isotonik dalam kemasan berukuran $250 \mathrm{cc}$ mengandung lebih Jurnal Gizi Volume 8 No 2 Tahun 2019 dari $5 \% \quad(110 \mathrm{mg})$ natrium dapat mempercepat pemulihan denyut nadi dibandingkan minuman isotonik dalam kemasan yang berukuran $350 \mathrm{cc}$ yang mengandung $2 \% \quad(45 \quad \mathrm{mg})$ natrium (Hidajah, 2011).

Pada penelitian ini subyek juga diberikan minuman kontrol yaitu air gula sebanyak $300 \mathrm{ml}$ dengan frekuensi satu kali pemberian. Berdasarkan hasil uji statistik bahwa terdapat pengaruh yang signifikan pada pemberian minuman pada kelompok kontrol terhadap denyut nadi sebelum latihan, 5 menit setelah latihan, 10 menit setelah latihan dan 15 menit setelah latihan dengan nilai $p<0,05$. Denyut nadi pada kelompok kontrol mengalami penurunan, tetapi tidak sebanyak denyut nadi pada kelompok perlakuan. Hal ini disebabkan oleh kandungan minuman kontrol hanya glukosa saja (4 g atau karbohidrat 8\%).

Hal ini berbanding lurus dengan pendapat Irawan mengenai pergantian cairan pada atlet yang berolahraga. Atlet yang melakukan olahraga apabila hanya mengkonsumsi minuman berkarbohidrat dapat menyebabkan hiponatremi. Kondisi hiponatremi ini dikarenakan ketidakseimbangan jumlah air dan natrium. Natrium berfungsi mempercepat proses pemulihan denyut nadi (Irawan, 2007). 
Hasil uji statistik menunjukkan bahwa terdapat perbedaan yang signifikan $(p<0,05)$ pada kelompok perlakuan dan kontrol terhadap denyut nadi sebelum latihan, 5 menit setelah latihan, 10 menit setelah latihan dan 15 menit setelah latihan. Minuman pada kelompok perlakuan mengandung 4,104 g glukosa (8\% karbohidrat) dan $0,5 \mathrm{~g}$ natrium, sedangkan minuman pada kelompok kontrol hanya mengandung 4 g glukosa $(8 \%$ karbohidrat). Perbedaan minuman pada kedua kelompok tersebut adalah kandungan $\mathrm{NaCl}$ yang terdapat pada minuman perlakuan.

Cairan ekstraselular tubuh dapat digantikan oleh kandungan natrium dalam minuman isotonik yang berfungsi mempertahankan keseimbangan air dan asam basa serta sebagai stimulus saraf, kontraksi otot serta membantu pemulihan denyut nadi (Irawan, 2007).

\section{SIMPULAN DAN SARAN}

Tidak terdapat pengaruh yang signifikan pada pemberian minuman kombinasi sari kurma (Phoenix dactylifera) dan garam $\mathrm{NaCl}$ terhadap tekanan darah. Terdapat pengaruh yang signifikan pada pemberian minuman kombinasi sari kurma
(Phoenix dactylifera) dan garam $\mathrm{NaCl}$ tehadap pemulihan denyut nadi.

Diharapkan penelitian selanjutnya melakukan uji kandungan zat gizi pada minuman kombinasi sari kurma dan garam $\mathrm{NaCl}$ dan melakukan uji osmolaritas pada minuman kombinasi sari kurma dan garam $\mathrm{NaCl}$.

\section{DAFTAR PUSTAKA}

Afriani, Y. (2014). Efektivitas Pemberian Minuman Kombinasi Maltodekstrin dan Vitamin C terhadap Mood, Kecemasan, Tekanan Darah, Denyut Nadi dan Daya Tahan Kardiorespirasi Atlet Sepak Bola. Thesis. Universitas Gadjah Mada.

Dorfman, L. (2008). Nutrition for Exercise and Sport Performance, In: Mahan LK, Sylvia Escott-Stump. Krause's food, nutrition \& diet therapy. 11th ed. Philadephia: Saunders.

Guyton, A., \& Hall, J. (2008). Textbook of Medical Physiology. Philadelphia: WB Saunders.

Halonen, J., Zanobetti, A., Sparrow, D., Vokanos, P., \& Schwartz, J. (2010). Relationship between outdoor temperature and blood pressure. Occup Environ Med. Published online on

http://oem.bmj.com

Herawati, M. (2013). POMNAS 2013 Sepak Bola DIY Masuk Final. www.harianjogja.com/baca/2013/11 48/pomnas-2013-sepak-bola-diyt masuk-final-469432, diakses pada 21 Oktober 2017.

Hidajah, N. (2011). Kandungan Natrium 2\% dan 5\% Dalam Minuman Isotonik Memperpendek Waktu Pemulihan. 


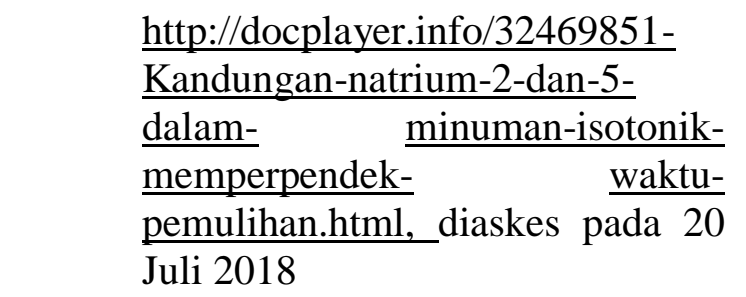

Irawan, M. (2007). Konsumsi Cairan dan Olahraga. Sport Science Brief. Vol 01 (02).

Irianto, D. (2007). Panduan Gizi Lengkap dan Olahragawan. Yogyakarta: PT. Andi Offset.

Kirkendall, D. (2004). Creatinine, Carbs, and Fluid: How Important in Soccer Nutrition SportsScience Exchange.17: 3.

Krisnawati, D. (2011). Efek Cairan Rehidrasi terhadap Denyut Nadi, Tekanan Darah dan Lama Periode Pemulihan. Universitas Negeri Semarang.

Koswara, S. (2009). Minuman Isontonik. THP Universitas Brawijaya. Jakarta: Pustaka Sinar Harapan.

Meludu, S., et al. (2005). Exercise performance in relation to glucose drink and their effect on some biochemical parameters. Nigerian Journal Of Physiological Sciences 20(1-2):43-47.

Murray, R., \& Stofan, J. (2001). Formulating CarbohydrateElectrolyte Drinks for Optimal Efficacy. Boca Ratio-Landon-New York-Washington DC: CRC Press.

PSSI. (2013). Timnas U-23 Kembali Meraih Perak. www.pssi.or.id. Diakses pada 20 Oktober 2017.

Saharullah. (2017). Perbandingan Pemberian Minuman Air Putih dengan Minuman Isotonik Terhadap Pemulihan Denyut Nadi pada Pemain Hoki FIK UNM.

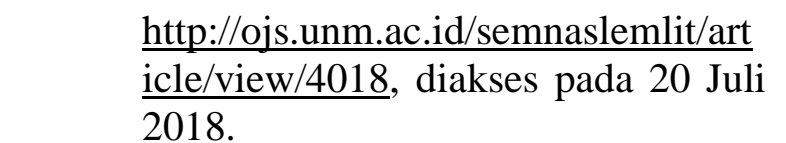

Singh, A., Chaudhary, S., \& Sandhu, J. (2011). Efficacy of Pre Exercise Carbohydrate Drink (Gatorade) on the Recovery Heart Rate, Blood Lactate and Glucose Levels in Short Term Intensive Exercise. Serbian Journal Of Sport Sciences; 5 (1): 29-34.

Tomas S, Karim C, Calro C, \& Ulrik W. (2013).Physiology of \begin{tabular}{l} 
Soccer: an 1 update. \\
\$www.skautingtimdif.rs/biblioteka_tn \\
\hline ning/Physiology_soccer_Update.pdf \\
\hline diakses pada 22 Oktober 2017. \\
lliams M. (2007). Nutrition for health, \\
fitness, and sport. 8th edition. New \\
York: Mc Graw-Hill Companies, \\
inc; p.118- \\
120;122;124;125;128;129;130.
\end{tabular}

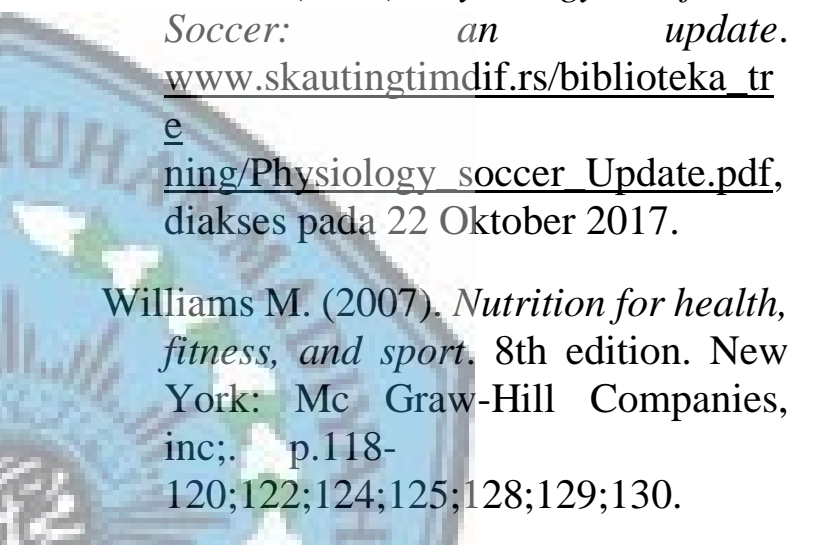

